\title{
Extrapallial abscesses associated with chronic bacterial infections in the intensively cultured juvenile Pacific oyster Crassostrea gigas
}

\author{
Ralph A. Elston ${ }^{1, *}$, Paul Frelier ${ }^{2}$, Dan Cheney ${ }^{3}$ \\ ${ }^{1}$ AquaTechnics and Pacific Shellfish Institute, PO Box 687, Carlsborg, Washington 98324, USA \\ ${ }^{2}$ Dept. Veterinary Pathology and Microbiology, College of Veterinary Medicine, Texas A \& M University, College Station, \\ Texas 77843-4463, USA \\ ${ }^{3}$ Pacific Shelliish Institute, 120 State Ave. N.E. \#142, Olympia, Washington 98501-0600, USA
}

\begin{abstract}
During a detailed survey of Pacific oyster Crassostrea gigas juvenile health at intensive rearing facilities, an episode of persistent morbidity and mortality occurred over an 8 wk period in 1997. Affected oyster seed were typically between about 1.0 and $2.4 \mathrm{~mm}$ in shell height. Abscesses were formed in the extrapallial space resulting from invasion by straight bacterial rods along the inner shell surface. The abscesses contained host cells and bacteria. The infection appeared to be chronic, was associated with relatively low numbers of bacteria cells, and caused alterations of the underlying mantle and abnormal shell deposition. No signs of any other type of infectious agent were found associated with the lesions. After a chronic time course, 2 outcomes were possible: either the mantle was breached, leading to an overwhelming terminal bacterial infection or, in some cases, host cell debris and bacteria were sequestered by new shell deposition and the infection was resolved. The condition can cause mortality and significant loss of growth in intensively cultured juvenile oysters.
\end{abstract}

KEY WORDS: Bivalve mollusc - Oyster Bacterial infection - Extrapallial Health management . Aquaculture

\section{INTRODUCTION}

Intensive production of larval and juvenile bivalves was developed on a pilot scale as early as the late 1950s (Walne 1958) and has been commercially practiced since the 1970s. Such technology has been pioneered for large-scale production on the West Coast of the United States for various species of bivalves including the Pacific oyster Crassostrea gigas, which is the most cultured oyster worldwide. In Washington State, a center for intensive oyster growing, and in some other areas of the world, the oyster industry is dependent on the successful production of seed oysters from hatcheries and nurseries.

Since the earliest reports of culture experimentation (Walne 1958), bacterial infections have been reported and later studied in some detail, particularly in larval

•E-mail: aquatech@olypen.com bivalves (e.g Tubiash et al. 1965, Brown 1973, Elston \& Leibovitz 1980) and are often associated with infection by vibrio bacteria. These infections can be troublesome but are generally manageable by surveillance and control measures in the intensive culture system (Elston 1984). Bacterial infections of the postmetamorphic or juvenile stage bivalves are less well understood and studied. Dungan \& Elston (1988) and Dungan et al. (1989) reported a ligament infection in Pacific oyster seed caused by gliding bacteria. Losses of juvenile oysters in a variety of locations, such as those of Crassostrea virginica along the Atlantic coast of North America that are termed juvenile oyster disease (Bricelj et al. 1992, Barber et al. 1996), are of unknown etiology. Diseases of juvenile oysters and other bivalves in intensive husbandry are far more economically significant than diseases of the larval stage because more time and effort have been invested in rearing the older juvenile shellfish. 
To increase the health status and efficiency of juvenile oyster production on the West Coast of North America, we initiated a oyster seed health program in 1996 that included a survey of seed health and diseases at intensive production facilities in Washington and other West Coast states. Our approach in this program was to intentionally focus on the gross and microscopic examination of organs and tissues of sick shellfish to provide an accurate representation of disease processes. One of the primary benefits of this approach is that it avoids the mistake of microbiological characterization without understanding the nature, course, and consequences of the disease on the affected bivalve. In this article we describe the occurrence and nature of chronic bacterial abscesses that occur between the inner shell surface and mantle (extrapallial space) of Pacific oyster juveniles. These infections can cause a significant, if transient, reduction of seed growth and survival in intensive culture systems.

\section{MATERIALS AND METHODS}

More than 240 cultures of both diploid and triploid larval and juvenile Pacific oysters Crassostrea gigas and Kumomoto oysters Crassostrea sikamea were examined sequentially through their development during 1996 and 1997 at 3 commercial production facilities in Washington State and at 1 facility in California. During the months of June and July 1997, Pacific oysters cultured initially in an upwelling apparatus and later transferred to a seed raft facility at a shell height between 1 and $3 \mathrm{~mm}$ exhibited persistent mortality and morbidity that could not be alleviated by repeated disinfection of the upwelling system and introduction of new oysters.

During this morbidity and mortality episode, 9 samples of the seed oysters from the affected sites were collected for clinical and microscopic examination. Samples of juvenile oysters were shipped chilled to the laboratory, where they were received and examined within $24 \mathrm{~h}$ of sampling. Mortality was estimated by examining a field of oysters with a stereomicroscope and enumerating empty shells and living oysters. Shell height was measured and representative oysters were preserved for histological examination. All oysters were fixed whole in the shell in Davidson's fixative and further decalcified as needed. Oysters less than $5 \mathrm{~mm}$ in shell height were embedded in a plastic histological medium (Elston et al. 1982) and stained with hematoxylin and eosin and a Giemsa stain. Larger oysters were prepared for histological examination using routine paraffin embedding techniques.
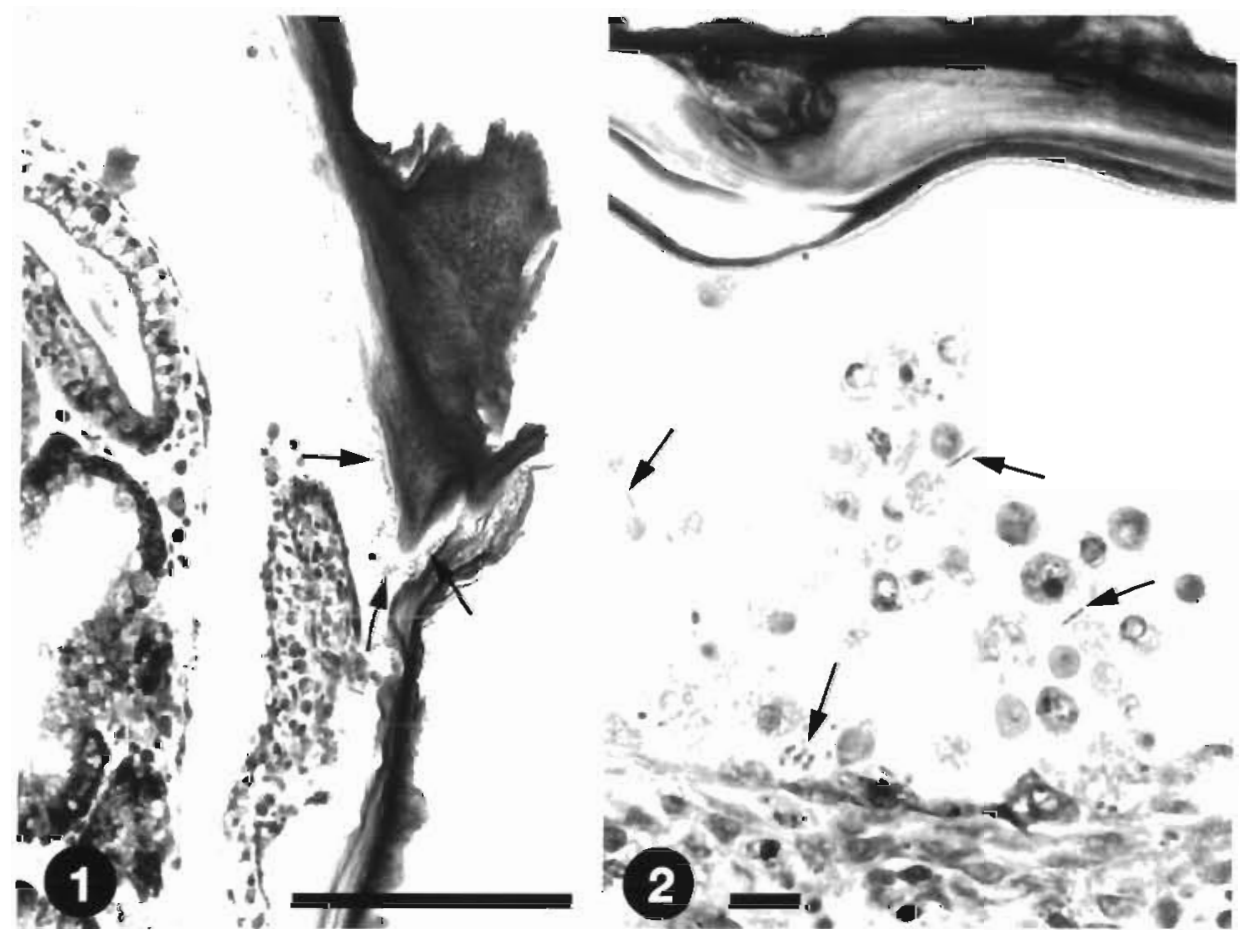

Figs. $1 \& 2$. Fig. 1. Crassostrea gigas. Section through juvenile oyster tissue and shell (vertical dark structure on right-hand side of figure), extrapallial space, and soft tissues. Arrows show examples of bacterial. cells attached to the interior surface of the shell. The valve junction is shown by the right-hand arrow. Giemsa stain. Scale bar $=100 \mu \mathrm{m}$. Fig. 2 . Section through a bacterial abscess showing rounded detached host cells in the extrapallial space and rod-shaped bacteria (arrows). Giemsa stain. Scale bar =10 $\mu \mathrm{m}$ 


\section{RESULTS}

\section{Mortality estimation and wet mount examinations}

Mortalities were reported from the seed nursery beginning in early June 1997 but by the end of July the problem had abated. Highest losses were reported by the nursery operator in seed whose shell height was 1.0 to $2.4 \mathrm{~mm}$. Several batches of oyster seed were discarded in their entirety both from the nursery upwellers and from the seed rafts due to high mortality. In the sample from the intensive upwelling facility received on June 24, 26.2\% (16/61) examined stereomicroscopically were active while the remaining were moribund or dead (Table 1). Other seed from the rafts received on the same date had more than $90 \%$ live oysters. From the second set of seed received on July 14, Sample 8 consisted of 9 of 31 (29.0\%) live oysters and Sample 9 consisted of $96 \%$ live and active oysters.

\section{Histological examination}

Lesions and bacteria associated with the shells were found to some extent in all groups. In Samples 1 and 8 , lesions were found in more than $80 \%$ of the individuals
Table 1 Date, location and size of samples examined in study

\begin{tabular}{|lcccc|}
\hline $\begin{array}{l}\text { Sample } \\
\text { no. }\end{array}$ & $\begin{array}{c}\text { Sample date } \\
\text { (1997) }\end{array}$ & $\begin{array}{c}\text { Sample } \\
\text { location }\end{array}$ & $\begin{array}{c}\text { Shell height } \\
\text { range in mm }\end{array}$ & $\begin{array}{c}\text { \% Live } \\
\text { oysters }\end{array}$ \\
\hline 1 & Jun 24 & $\begin{array}{c}\text { Nursery } \\
\text { upwellers }\end{array}$ & $1.8-2.4$ & 26.2 \\
$2-6$ & Jun 24 & Seed raft & $1.0-8.0$ & $>90$ \\
8 & Jul 14 & Seed raft & $1.1-2.1$ & 29.0 \\
9 & Jul 14 & Seed raft & $0.6-1.3$ & 96.0 \\
\hline
\end{tabular}

examined histologically but in less than $20 \%$ of individuals in the other groups.

Bacterial cells were commonly found on the external shell surface of seed oysters. In affected individuals, bacteria typically consisted of straight rods that were attached to the internal shell surface and found within abscesses (Figs. $1 \& 2$ ). Bacterial cells were very difficult to differentiate in hematoxylin and eosin (H\&E)stained tissues but were relatively easy to discriminate in the Giemsa-stained preparations. Abscesses were formed in the extrapallial space, between the inner shell surface and the mantle. These were located at various points along the lateral mantle and occasionally at the juncture of the left and right valves (Figs. 3 \& 4). The abscesses tended to be focal and relatively localized in the extrapallial space. They contained a

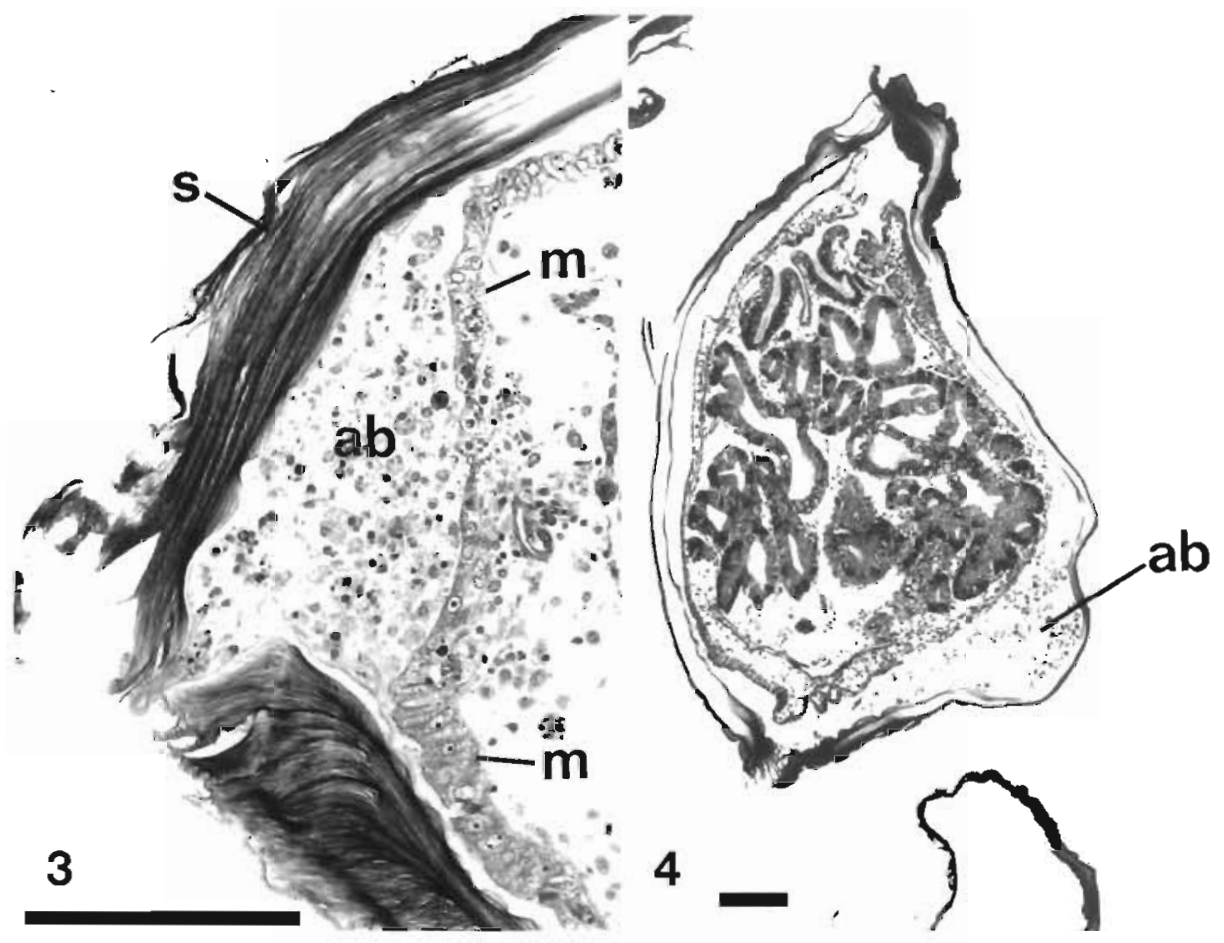

Figs. $3 \& 4$. Fig. 3. Crassostrea gigas. Section of juvenile oyster showing an abscess (ab) bounded by the shell matrix (s) and mantle $(\mathrm{m})$. Between the 2 markers showing the mantle $(\mathrm{m})$, the epithelium is considerably flattened and contains rounded degenerating cells. Giemsa stain. Scale bar $=100 \mu \mathrm{m}$. Fig. 4. Transverse section through juvenile oyster showing an abscess (ab) in the extrapallial space. The extrapallial space on the left-hand side of the oyster is normal. Giemsa stain. Scale bar $=100 \mu m$ 


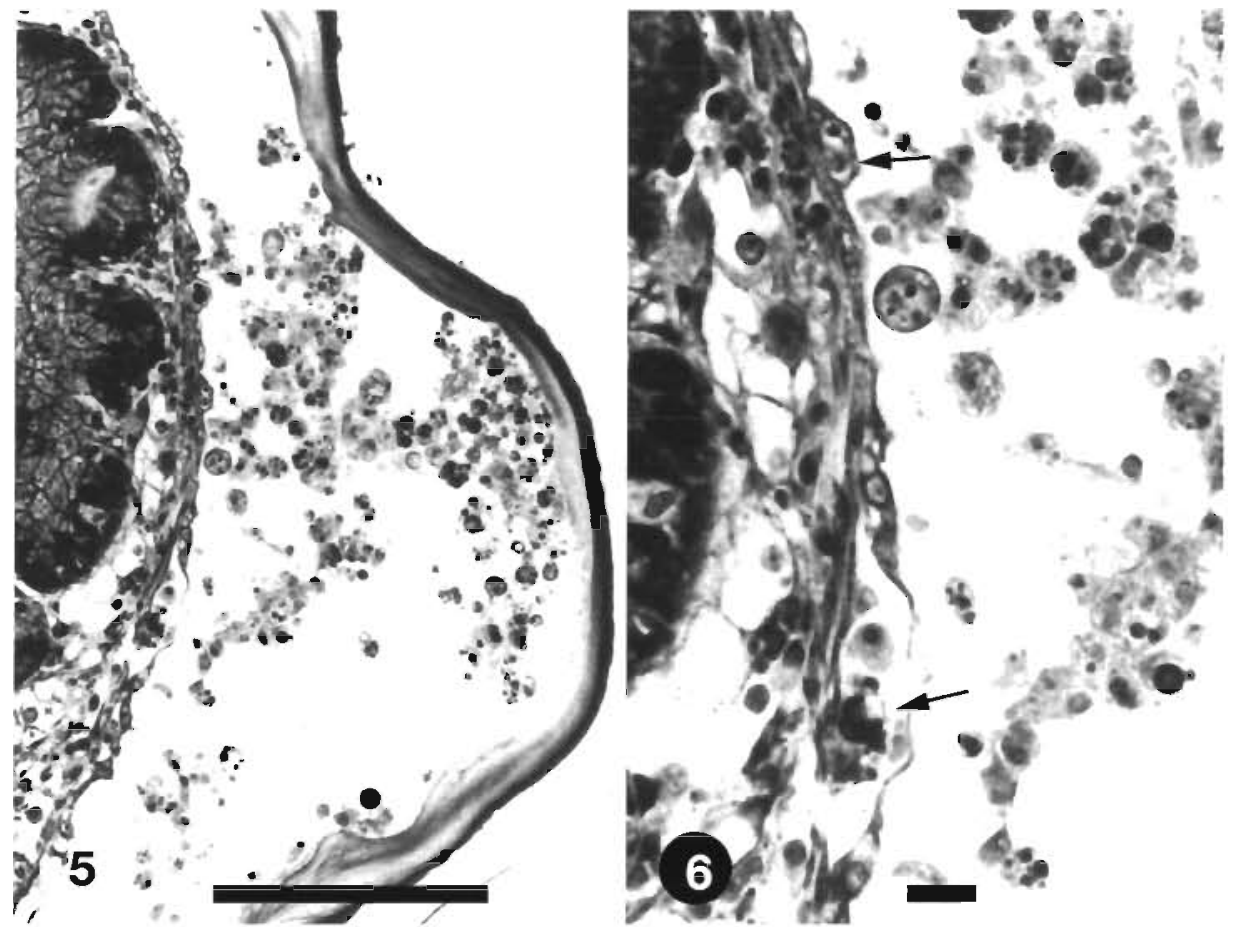

Figs. 5 \& 6. Fig. 5. Crassostrea gigas. Enlarged portion of the juvenile oysters shown in Fig. 4 showing an abscess located in the area of an apparent shell malformation in which a pocket containing the abscess has formed. Giemsa stain. Scale bar $=100 \mu m$. Fia. 6. Enlarged area of the abscess shown in Fig. 5 containing cell debris and rounded, detached host cells. The mantle epithelium is flattened and contains rounded degenerating cells (arrows). Giemsa stain. Scale bar $=100 \mu \mathrm{m}$

mixture of moribund host cells, host hemocytes, and bacteria (Figs. 5 \& 6).

The mantle adjacent to these abscesses usually was not breached but the pallial epithelium was markedly flattened and contained rounded mantle epithelial cells (Figs. 2, 3, 5 \& 6) with nuclei in various stages of degeneration. Cross sections of the shell adjacent to abscesses suggested that chronic infections resulted in an abnormal pattern of shell deposition and, in some cases, formation of pockets containing the necrotic cells and bacteria, formed as normal shell growth proceeded in adjacent areas (Figs. 4 \& 5). Bacteria attached to the shell and in the abscesses were usually rod shaped. Within the abscesses, small numbers of bacteria and necrotic host cell debris were found within host hemocytes, as were nonphagocytosed cell debris and the bacterial cells.

In a few specimens, bacterial cells and host cell debris were found sequestered between layers of shell material. Several lamina of shell separated the bacteria from the pallial cavity. All histological material was examined in detail for the presence of nuclear or cytoplasmic inclusion bodies indicative of viral infections, for parasites, and for the presence of bacterial hinge ligament disease. None of these was found.

\section{DISCUSSION}

Samples examined during the course of an episode of morbidity and mortality are of necessity limited in terms of representing the overall event, particularly as they relate to case studies at production facilities. Thus, the overall mortality rate in this instance can only be estimated from the production records. When mortality is sufficient to justify discarding entire production lots, it is generally quite high, certainly in excess of $50 \%$ and often much higher. The information in these samples that was available to estimate death losses showed that the cumulative loss rate, as measured by enumerating single samples, could be as high as about $74 \%$. Of course, such mortality estimates indicate a point-in-time condition only and the actual death losses, mathematically integrated over time, are higher than the instantaneous rate and depend on the time course and outcome of the disease. The disease process observed in this study clearly occurred both in the nursery upwelling system and in the seed rafts, based on its observation in both Samples 1 and 8 . It is our presumption that the process was initiated in the upwelling system and transferred to the nursery rafts as the mortality losses were reported in both systems. No losses were reported after July 1997. 
The histological findings support the thesis that this is a chronic primary bacterial disease. The bacterial nature of the disease is demonstrated by the pathway and pattern of sequential invasion of bacteria along shell surfaces in living oysters. In addition, detailed examination did not reveal evidence of any other infectious agents, including viral inclusion bodies. Several features of the disease suggest that it is chronic. From the pathological point of view, the high proportion of individuals in the affected groups that had infections consisting of damaged but unbreached mantle epithelium suggests a chronic course of the disease. In addition, the occasional sequestration of bacteria and host cell debris between successively deposited layers of periostracal lamina by shell growth from the interior aspect and the apparent alteration of normal shell deposition would also be associated with a chronic process. These features of the disease suggest slow-growing but persistent bacteria, a partially effective host response, and possibly some capacity for repair of the damaged mantle, particularly as the oyster seed increase in size to more than about $2.4 \mathrm{~mm}$ in shell height. The fact that the nursery operators reported continuing losses over about an 8 wk period, beginning in early June, also indicates the chronic nature of the process. However, the reported mortality and occasional observation of overwhelming bacterial infections throughout the soft tissues indicates that, in some individuals at least, the infection can have a terminal outcome.

It is important to differentiate this disease from acute bacterial infections of the extrapallial space and mantle, which have a rapid course and are typified by an outcome of overwhelming bacterial infection of soft tissues, as described by Elston (1984) and Dungan \& Elston (1988). Such infections are typical of rapid losses of large numbers of seed under suboptimal culture conditions. It is also useful to clarify that the disease described here is the result of mantle cells being shed into the extrapallial space at a rate that does not exceed the capacity of the mantle for repair, except in those cases where the infection eventually becomes terminal. Since the extrapallial space contains apparently living host hemocytes, necrotic mantle cells, and bacteria, this pathological manifestation is termed an abscess. In contrast, the rapidly progressive infections, which also proceed as bacteria invade along the inner shell surface, result in rapid and complete destruction of mantle epithelium and are not characterized by a thinned mantle epithelium and the presence of contained abscesses in the extrapallial space, as observed in the chronic form of the disease.

A variety of diseases that have been reported in bivalve molluscs are characterized by infectious processes which occur in the extrapallial space. Elston \& Leibovitz (1980) and Elston et al. (1981) reported a bacterial infection of rapid course in eastern oyster larvae
Crassostrea virginica in which vibrio bacteria attached to the shell surface grew between the valve openings and along the inner shell surface, destroying adjacent mantle. A similar pattern of invasion characterized the ameboflagellate infection of geoduck larvae Panope abrupta reported by Kent et al. (1987). The hinge ligament infections reported by Dungan \& Elston (1988) are clearly a different disease, but those authors concluded bacterial lesions sometimes found in the mantle of seed oysters could result after the hinge ligament was breached. The current study shows that a common infection route is simply by growth along the shell surface at the margins from the outer to inner aspect of the shell. However, the large numbers of bacteria often found at the exterior aspect of the peripheral shell suggest that a host defensive mechanism is in place to retard such growth into the pallial cavity.

A significant disease reported recently that involves infection of the extrapallial space is brown ring disease (BRD) of juvenile and adult manila clams Tapes philippinarum (Paillard et al. 1994). This disease consists of infection by Vibrio tapetis (Borrego et al. 1996), which apparently localizes on the interior shell surface and disrupts the normal deposition of periostracal lamina. Grossly, the clams have melanized deposits along the periphery of the inner shell surface, hence the name brown ring disease. Microscopically, the lesions consist of progressive deposition of lamina and calcification to isolate the bacteria and host cell debris, which apparently can lead to a recovery process. Paillard \& Maes (1995a) described the attachment and colonization bacteria on the periostracal lamina and the subsequent erosion and curling of this organ, followed by the invasion of the fibrous matrix of the shell. In experimental studies, Paillard \& Maes (1995b) described the formation of both pustules on the inner shell surface and a continuous bacterial film observed on the prismatic layer of the shell. In both BRD and the abscesses described here in juvenile oysters, attachment of bacteria to the periostracal and inner shell surface is a critical pathogenic feature. A difference between the disease reported here and BRD is that the disease of Pacific oysters affects only juveniles. The nursery production reports and the observed higher prevalence only in oysters about 1.0 to $2.4 \mathrm{~mm}$ in shell height suggest that as the oysters develop and grow larger, their ability to resist and recover from this disease increases. This hypothesis is further supported by the fact that, unlike BRD of clams, no disease of the periostracal lamina has been observed in adult oysters from the region of this study.

Mortalities of juvenile eastern oysters Crassostrea virginica have been reported from the East Coast of the United States since 1988 (Bricelj et al. 1992, Barber et al. 1996). No definitive etiological agent has been identified, and the condition should be termed a syndrome 
rather than a disease. Given the widespread occurrence of the syndrome spatially and temporally, it is likely that such losses may be caused by a number of factors and distinctive disease processes, possibly including a process similar to that described here. A series of sequential morphological assessments of so-called juvenile oyster disease would likely advance the understanding of the syndrome of eastern oyster losses.

Management of the disease reported here is limited to standard sanitation measures at this time. In the case reported here, the upwelling systems were disinfected 2 times during the interval of the disease, and highly affected groups were discarded. These measures were not effective during the morbidity and mortality episodes of June and early July. The retention of clinically healthy individuals that may have been infected at a low rate could have reinfected the system. The water system in use for nursery upwellers utilizes sand-filtered water. Thus, it is also possible that the system was continuously reinfected during the disease episode from an environmental source. Mortalities of this magnitude in the upwelling system studied here were reported as rare by the nursery operators. The 2 mo preceding this disease episode were characterized by exceptionally high rainfall and freshwater runoff to the estuary where the nurseries are located, suggesting that unusual environmental conditions could have resulted in an alteration of the typical bacterial populations present.

As noted in the 'Introduction', the importance of morphological examination to define diseases in bivalves, or any species for that matter, is a critically important early step in the process of disease characterization. This is particularly important in early life stages when the individuals are small and specific isolation of bacteria from a given organ or lesion is difficult. Even if the lesion is relatively accessible, it can be difficult to define a valid cause-and-effect relationship between the presence of microbes and the occurrence of diseases. By including and preferably initiating studies with morphological assessment, it is possible to assess the significance and nature of the disease in terms of tissue damage. Further studies are now needed to identify the bacteria which are capable of creating chronic abscesses in the extrapallial cavity of oysters.

Acknowledgements. This project was supported by grant number NA66FD0123 from the National Marine Fishery Service, U.S. Department of Commerce, Saltonstall-Kennedy program, to the Pacific Shellfish Institute.

Editorial responsibility: Albert Sparks, Seattle, Washington, USA

\section{LITERATURE CITED}

Barber BJ, Carnegie RB, Davis CV, Mook W (1996) Effect of timing of seed deployment on growth and mortality of oysters, Crassostrea virginica, affected by juvenile oyster disease (JOD). J World Aquacult Soc 27(4):443-448

Borrego JJ, Castro D, Luque A, Paillard C, Maes P, Garcia MT, Ventosa A (1996) Vibrio tapetis sp. nov. the causative agent of the brown ring disease affecting cultured clams Int J Syst Bacteriol 46:480-484

Bricelj VM, Ford SE, Borrero FJ, Perkins FO, Rivara G, Hillman RE, Elston RA, Chang J (1992) Unexplained mortalities of hatchery-reared, juvenile oysters, Crassostrea virginica (Gmelin). J Shellfish Res 11(2):331-347

Brown C (1973) The effects of some selected bacteria on embryos and larvae of the American oyster, Crassostrea virginica. J Invertebr Pathol 21(3):215-223

Dungan CF, Elston RA (1988) Histopathological and ultrastructural characteristics of bacterial destruction of hinge ligaments in cultured juvenile Pacific oysters, Crassostrea gigas. Aquaculture 72:1-14

Dungan CF, Elston RA, Schiewe M (1989) Evidence for colonization and destruction of hinge ligaments of cultured juvenile Pacific oysters (Crassostrea gigas) by cytophagalike bacteria. Appl Environ Microbiol 55:1.128-1135

Elston RA (1984) Prevention and management of infectious diseases in intensive mollusc husbandry. J World Maricult Soc 15:284-300

Elston R, Leibovitz L (1980) Experimental vibriosis in larval American oysters, Crassostrea virginica. Can J Fish Aquat Sci 37:964-978

Elston R, Leibovitz L, Relyea D, Zatila J (1981) Diagnosis of vibriosis in a commercial oyster hatchery epizootic, a case history. Aquaculture 24:53-62

Elston R, Elliott E, Colwell RR (1982) Conchiolin infection and surface coating Vibrio: shell fragility, growth depression and mortalities in cultured oysters and clams Crassostrea virginica, Ostrea edulis and Mercenaria mercenaria. $J$ Fish Dis 5:265-284

Kent ML, Elston RA, Nerad TA, Sawyer TK (1987) An isonema-like flagellate (Protozoa: Mastigophora) infection in larval geoduck clams, Panope abrupta. J Invertebr Pathol 50:221-229

Paillard C, Maes P (1995a) The brown ring disease in the manila clam, Ruditapes philippinarum. I. Ultrastructural alterations of the periostracal lamina. J Invertebr Pathol 65:91-100

Paillard C, Maes P (1995b) The brown ring disease in the manila clam, Ruditapes philippinarum. II. Microscopic study of the brown ring syndrome. J Invertebr Pathol 65: 101- 110

Paillard C, Maes P, Oubella R (1994) Brown ring disease in clams. Annu Rev Fish Dis 4:219-240

Tubiash HS, Chanley PE, Leifson E (1965) Bacillary necrosis, a disease of larval and juvenile bivalve molluscs. I. Etiology and epizootiology. J Bacteriol 90:1036-1044

Walne PR (1958) The importance of bacteria in laboratory experiments on rearing the larvae of Ostrea edulis (L.O.) J Mar Biol Assoc UK 37:415-425

Submitted: July 21, 1998; Accepted: February 2, 1999 Proofs received from author(s): June 16, 1999 